\title{
IMPLEMENTASI ZETIZEN BAGI DAYA TARIK LITERASI MEDIA GENERASI Z
}

\author{
Oleh : Haidir Fitra S, Tri Imam F \\ Dosen Jurusan Jurnalistik Fakultas Dakwah dan Komunikasi UIN \\ Alauddin Makassar \\ Email : hfitra.siagian@uin-alauddin.ac.id
}

\begin{abstract}
Implementation or activities undertaken by Zetizen PT. Jawa Pos Group in increasing reading interest of $Z$ generation towards the news which is presented with intergrating Zetizen newspaper published in 38 cities of 34 provinces in Indonesia, website zetizen.com with providing news contents, quizzes, and Zetizen members, social media to encourage the increase of awareness towards Zetizen products, both traffic website and newspaper readers, last offline engagement, by always being involved and creating Zetizen events and communities. Those four elements are interconnected within increasing reading interest of $Z$ generation. The challenges faced by Zetizen PT. Jawa Pos Group is divided into two. 1) Human Resources, including; a) diversification of spirit, lack of human resources, $b$ ) Zetizen crew must have courage, develop research and understand the condition of young people. And 2) Content, including: a) Make the Zetizen news become viral, attractive, communicative, b) lack of media distribution, c) updating timeline and interesting creative videos.
\end{abstract}

\section{Keywords :}

Implementasi, media, konten

\section{Pendahuluan}

Membaca berita memang sudah menjadi "makanan" pokok bagi setiap orang, khususnya anak-anak, remaja, dewasa hingga orang tua. Setiap hari tidak lepas dengan berita (news), baik itu berita yang diterbitkan di media massa seperti media cetak, elektronik, maupun media baru (new media) seperti online.

Namun saat ini tingkat pembaca khususnya di Indonesia cukup mengkhawatirkan.

Berdasarkaan data statistik United Nations of Educational Scientific, and Cultural Organization (UNESCO) pada 2012, menyebutkan indeks minat baca di Indonesia baru mencapai 0,001. Artinya, dari di 1000 penduduk, hanya satu yang memiliki minat baca (Republika 2015). Sementara hasil dari The World Most Literate Nations (WMLN) tahun 2003-2014, tingkat literasi tertinggi di dunia ditempati Finlandia, sedangkan di Indonesia sangat jauh, yakni berada di urutan ke-60 dari 61 negara yang diambil sampel ujinya. 
Hasil penelitian Programme for International Student Assessment (PISA) tahun 2015, minat membaca siswa di Indonesia menduduki urutan ke-69 dari 76 negara yang disurvei (Harian Jogja 2016).

Seiring perkembangan teknologi, informasi dan komunikasi yang semakin canggih, pembaca muda mulai berkurang, karena generasi remaja kini tentu mempunyai era yang berbeda. Misalnya membaca berita, berbagai alasan remaja seperti malas, karena dianggap bahwa membaca berita seperti di koran itu cocoknya bagi bapak-bapak saja. Padalah bagi semua usia itu perlu dan cocok membaca berita, tapi memilih gadget. Seperti itu terjadi di era kini.

Setelah era generasi baby boomers, $\mathrm{X}$, dan $\mathrm{Y}$, sekarang dikenal dengan nama generasi Z yang kini mendominasi populasi dunia. Anak-anak generasi Z lahir pada tahun 1995 ke atas, atau saat ini berusia 13-20 tahun di mana internet bisa diakses kapan dan dimana saja, serta smartphone, tablet hingga segway sudah menjadi "mainan" generasi Z. (Zetizen 2016).

Faktor terbesar mengapa generasi $\mathrm{Z}$ memiliki kebiasaan yang begitu berbeda dari generasi-generasi sebelumnya adalah teknologi. Maka, pendekatan ke remaja ini juga tentu berbeda, termasuk mempelajari keseharian mereka. Anak-anak sebelum generasi Z tentu memerlukan cara yang berbeda. Misalnya generasi Baby Boomers, generasi yang lahir dengan latar belakang setelah perang dunia kedua. Karakter dari generasi ini mempunyai sifat seorang pahlawan, belum mengenal yang namanya teknologi secanggih sekarang. Sehingga, perlakuan generasi ini juga harus berbeda. Tidak mungkin generasi ini disuguhi berita media massa dengan cara seperti saat ini.

Generasi X, anak-anak yang lahir di generasi ini adalah awal dari penggunaan Personal Computer $(P C)$, video games, dan internet. Namun media massa pada saat itu, seperti media cetak masih sangat diminati masyarakat. Belum ada noise yang terjadi seperti saat ini. Penggunaan internet dan PC masih terbilang minim. Apalagi remaja, tidak memiliki PC atau menggunakan internet untuk keperluan pribadi, di samping biaya yang sangat mahal.

Pada saat itu, hanya perusahaan besar yang membutuhkan alat seperti PC atau orangorang tertentu yang membeli dan menggunakan untuk keperluan pribadi. Bagaimana dengan generasi Y? Generasi yang dikenal dengan sebutan generasi milenial. Generasi ini 
sudah banyak yang menggunakan teknologi komunikasi yang instan, seperti surat elektronik atau dikenal dengan singkatan e-mail, SMS, instant messaging dan media sosial seperti Facebook dan Twitter, bahkan game online juga sudah ada. Penggunaan teknologi tersebut bagi generasi ini tidaklah sebanyak dan sesering generasi Z. Sehingga perlakuan anak yang lahir di generasi ini juga berbeda dengan generasi $\mathrm{Z}$.

Generasi $\mathrm{Z}$ atau biasa disebut iGeneration (generasi internet), sudah dapat mengaplikasikan berbagai kegiatan dalam satu waktu, misalnya menggunakan gadget untuk membuka media sosial, mendengarkan musik, nonton via internet menggunakan ponsel pintar (smartphone), atau bisa dikatakan kebanyakan berhubungan dengan dunia maya, dan populasi generasi inilah yang dominan saat ini. Hal itu bisa terjadi karena memang sejak kecil mereka sudah mengenal teknologi, bahkan sudah akrab. Sehingga secara tidak langsung kepribadian mereka sudah terpengaruh.

Zetizen mencoba menjawab beberapa pertanyaan yang krusial. Misalnya bagaimana membuat anak muda tetap membaca berita. Karena sekarang anak muda khususnya generasi $\mathrm{Z}$ selalu mengarah ke online. Mereka online tapi jarang membaca news, menonton TV tapi tidak menonton news. Apalagi saat ini perusahaan cetak dan digital tentu berbeda. Jualan usaha cetak semakin sulit, namun jualan digital juga tidak begitu mudah. Namun, tujuannya sama, yaitu meningkatkan pembaca dan omzet iklan. Hanya cara dan tantangan yang berbeda untuk melakukannya.

Zetizen tidak hanya terbit di koran cetak Jawa Pos Group, tapi juga melibatkan digital, yaitu zetizen.com. Hanya remaja yang termasuk generasi $\mathrm{Z}$ yang bisa berinteraksi di dalamnya. Hal ini dilakukan Zetizen sebagai wujud menyikapi zaman anak muda sekarang, menyesuaikan diri dengan kebiasaan para generasi Z. Akan berbahaya jika perusahaan koran hanya sibuk memberitakan yang bukan zaman generasi sekarang, yang sudah tidak dikenal oleh generasi yang mendominasi saat ini. Didukung pula dengan kru yang bekerja di Zetizen PT. Jawa Pos Group terdiri dari anak-anak muda yang rata-rata berusia 20 tahun. Sehingga cara menyiapkan hingga menyajikan konten-konten ataupun program yang dijalankan Zetizen bisa sesuai dengan target pembaca. Artinya yang menyiapkan anak muda untuk pembaca muda.

Persoalan yang dibahas pada penelitian ini untuk mengetahui implementasi yang dilakukan Zetizen PT. Jawa Pos Group dalam meningkatkan minat baca generasi Z 
terhadap berita. Maksudd dari implementasi dalam hal ini merupakan pelaksanaanpelaksanaan berupa aktivitas apa saja yang dilakukan kru Zetizen PT. jawa Pos Group yang sesuai dengan kebutuhan generasi $\mathrm{Z}$, sehingga mampu meningkatkan minat baca generasi $\mathrm{Z}$ terhadap berita.

\section{Pembahasan}

A. Implementasi Zetizen PT. Jawa Pos Group Meningkatkan Minat Baca Generasi Z terhadap Berita

Impelementasi Zetizen PT. Jawa Pos Group dalam penelitian ini merupakan aktivitas, proses kerja, atau tindakan yang dilakukan crew Zetizen PT. Jawa Pos Group dalam mencapai visinya meningkatkan minat baca generasi Z. Sesuai hasil penelitian yang dilakukan oleh peneliti, Zetizen menerapkan penyajian berita dengan mengintegrasikan halaman koran, website, social media, dan offline engagement.

\section{Halaman Koran}

Kekuatan halaman anak muda Jawa Pos Group yaitu menyajikan konten anak muda yang berkualitas, tema yang beragam, serta sesuai dengan tren terbaru di masingmasing kota. Meski Zetizen Indonesia terbit secara nasional, namun setiap koran yang menerbitkannya tetap harus menyajikan konten lokal yang sesuai dengan keadaan di daerahnya masing-masing. Gaya penyajian berita dibuat lebih ringkas, easy reading, dan atraktif (banyak bermain visual foto dan infografis). Perubahan sajian konten di koran yang lebih ringkas dan atraktif memberikan alternatif bacaan yang berbeda dengan yang didapatkan di internet. Hal ini dapat mendorong pembaca untuk menantikan edisi-edisi selanjutnya setiap hari.

Supervisor Redaksional Zetizen PT. Jawa Pos Group, Indriani Puspitaningtyas beserta timnya juga melakukan perencanaan setiap hari, baik dalam rapat ataupun jika ada waktu luang untuk membahas perencanaan. Zetizen juga mempunyai cara khusus dalam meningkatkan minat baca generasi $\mathrm{Z}$ melalui platform halaman koran, seperti yang dijelaskan Indiani Puspitaningtyas, bahwa salah satu caranya dengan mengemas berita di sosial media dan media interaktif di koran. "Media interaktif ini seperti kuis dan juga games. "Kami ada halaman mindgames yang diintegrasikan di koran, website, dan social media Zetizen.” ～(Indriani Puspitaningtyas, 
Wawancara, Kamis, 12 Oktober 2017). Halaman koran Zetizen tidak dikemas begitu saja,namun menurut Supervisor Community Development Zetizen PT. Jawa Pos Group, Faisal Ash Shiddiq, halaman koran Zetizen itu segi pemberitaannya harus mempunyai news velue dan tentunya yang sesuai dengen segmentasi Zetizen, yaitu generasi $\mathrm{Z}$.

Dari segi halaman Zetizen kita buat tidak monoton, halaman harus terus berubah-ubah. Paling gampang dari segi tema. Temanya tidak boleh ada yang sama dan berulang kali. Bahkan dua kali saja tidak boleh. Kalaupun berulang kali itu sifatnya membandingkan atau mengevaluasi. Misalnya tema yang diangkat itu tentang bully. Tema itu sudah pernah diangkat tahun sebelumnya, kalau memang harus diangkat lagi boleh, asalkan pembahasannya harus beda dari yang sebelumnya. (Faisal Ash Shiddiq, Wawancara, Senin, 9 Oktober 2017).

Zetizen berupaya untuk membuat tema yang tidak berulang-ulang atau tema yang sudah pernah terbit, sehingga berita-berita yang diterbitkan tidak monoton. Hal ini membuat crew Zetizen harus selalu memikirkan tema apa saja yang akan diterbitkan setiap minggunya. Halaman koran Zetizen dapat dikatakan wajib full color, demi memenuhi kebutuhan generasi $\mathrm{Z}$ sebagai pembacanya. Sehingga Zetizen butuh menerapkan pemerataan standar desain halaman yang akan menjadi patokan para graphic designer Zetizen. Faisal Ash Shiddiq mengatakan, walaupun desain itu sesuai selera designer, tapi tetap harus ada standarnya dalam hal komposisi.

Bagi Zetizen, menyamakan standar desain itu sangat penting, sehingga hasil yang dicapai bisa lebih memuaskan. Selain standar desain, ada hal lain yang bisa diintegrasikan dengan pembaca di halaman koran.

Zetizen melakukan berbagai tahap dalam membuat berita di halaman Koran agar menarik pembaca generasi Z. Mulai dari tahap perencanaan dalam rapat tema, pembuatan polling, peliputan, pengeditan, layout, pengecekan ulang, penerbitan hingga evaluasi.

Tahap perencanaan tema, supervisor redaksional mengadakan rapat besar untuk divisi redaksional Zetizen. Rapat tersebut berlangsung sekali dalam seminggu, yakni hari Jumat atau Sabtu malam, tergantung kondisi. Pada tahap ini, editor dan reporter diwajibkan mengusulkan minimal dua tema yang akan diterbitkan. 
Setelah itu di proofing ke supervisor redaksional. Kalau tema yang diusulkan diterima, maka lanjut ke tahap selanjutnya. Jika tidak, akan listing tema lagi. Setelah semuanya diterima, maka lanjut ke tahap pembuatan zetpolls, atau pembuatan polling berupa survei beberapa pertanyaan yang dimuat di website zetizen.com. Setelah hasil survei tersebut sudah dijawab member Zetizen di website, maka diperoleh hasil yang akan dijadikan angle khusus dari masing-masing tema. Setelah itu barulah reporter membuat naskahnya, sesuai dengan porsi naskah yang dibagikan editor. Reporter dan photographer Zetizen kemudian menjalankan tugas utamanya, yakni mencari dan membuat berita sesuai list tema yang telah disepakati.

Membuat list sebelum meliput cukup memudahkan reporter Zetizen saat berada di tempat liputan, proses wawancara bisa lebih cepat dan terarah. Saat melakukan wawancara, dia mengatakan seakan-akan tidak sedang meliput. Ini merupakan salah satu cara dia untuk mendapatkan data.

Membuat berita yang lebih detail serta menggunakan bahasa yang ringan dan tidak baku, cocok diterapkan dalam pembuatan berita Zetizen. Generasi Z akan lebih mudah memahami jika penyajian beritanya tidak terlalu serius. Photographer Zetizen tentu juga memiliki aktivitas tersendiri dalam menjalankan tugasnya. Untuk menarik minat baca generasi $\mathrm{Z}$ agar semakin meningkat, ada teknik khusus dalam pengambilan foto yang dilakukan photographer Zetizen. Selain teknik foto, model bagi photographer Zetizen tentu sangat dibutuhkan, khususnya untuk melengkapi foto headline.

Setelah naskah berita dan foto halaman koran selesai, reporter dan photographer kemudian mengirimkan naskah dan foto mereka ke editor halaman koran yang bertugas. Biasanya reporter mengirim via email ke editor yang bertugas, juga biasanya via server Jawa Pos.

Editor halaman koran kemudian mengedit naskah menggunakan Microsoft Word di computer Zetizen Jawa Pos. Seperti Almas Salsabil, editor halaman koran menggunakan aplikasi tersebut agar proses editing lebih mudah. Seperti membuat tulisan italic (miring), kutipan dan sebagainya. Almas Salsabil dan editor lain juga terkadang membuka buku halaman koran Zetizen yang sudah terbit sebelumnya untuk mengecek gaya penulisan, atau mencari inspirasi untuk membuat naskah yang diedit semakin menarik. "Membaca hasil editan editor lain itu perlu, agar self improve, 
mengembangkan gaya mengedit berita." (Almas Salsabil, Wawancara, Kamis, 5 Oktober 2017). Almas Salsabil kemudian menjelaskan, tahapan-tahapan yang dia lakukan sebagai editor halaman koran Zetizen mulai dari mengetahui dan memahami naskah yang mau dia edit.

Setelah tahap editing sudah selesai, naskah dan foto yang sudah diperiksa editor kemudian dikirim ke server bagian graphic designer Zetizen. Divisi graphic design lalu bertugas untuk me-layout naskah berita dan foto serta kebutuhan lain menjadi sebuah halaman koran. Peneliti melihat designer halaman koran Zetizen bekerja menggunakan iMac, yaitu komputer produk Apple, dengan spesifikasi yang sesuai untuk membuat desain grafis. Designer Zetizen menggunakan software Adobe Indesign, software yang sudah lumrah digunakan para layouter koran, majalah, buku dan koran digital, dan sebagainya. selanjutnya designer harus paham betul statement yang akan di-layout. Sehingga pesan berita yang akan diterbitkan nanti bisa tersampaikan.

Designer biasanya mencocokkan statement konten halaman seperti tema dan foto kepada editor dan reporter maupun photographer, sehingga ada kesepahaman antara mereka. Cara yang diterapkannya tersebut ternyata berpengaruh terhadap generasi $\mathrm{Z}$ yang melihat halaman koran Zetizen hasil layout-nya. Dia yakin juga dengan cara tersebut bisa meningkatkan minat baca generasi $\mathrm{Z}$.

Data sekunder yang didapat peneliti, karakteristik konten pada website Zetizen yaitu; kontennya keren, beragam, dan terkini, sajian informasinya banyak membahas faktafakta ringan yang berhubungan dengan big issue, atau cerita di balik layar, pemilihan diksi harus popular, menggelitik, atau kontroversi-onal, walau tampilan visual bukan hal yang utama.

Generasi $\mathrm{Z}$ lebih terbiasa dan mungkin lebih nyaman membuka website daripada halaman koran. Integrasi konten antara website, halaman koran, dan social media dapat mengarahkan pembaca untuk juga membuka koran.

Supervisor Community Development Zetizen PT. Jawa Pos Group, Faisal Ash menjelaskan, di website zetizen.com itu mengunggulkan konten, tidak jauh beda juga dengan halaman koran Zetizen 


\section{Social Media}

Zetizen PT. Jawa Pos Group tentu menggunakan social media. Zetizen melihat semua data survei, baik dalam jangkuan global ataupun Indonesia, menunjukkan adanya peningkatan yang signifikan tentang penggunaan sosial media, terutama pada user berumur di bawah 25 tahun. Sosial media dimanfaatkan untuk mencari dan menyebar informasi. Penguasaan digital content yang didistribusikan melalui sosial media adalah salah satu kunci keberhasilan dalam menarik perhatian netizen. Dengan mengintegrasikan keunikan sosial media dalam pembuatan konten berita mampu menghasilkan output positif terhadap pembaca, terutama dalam hal engagement dan brand awareness. Data sekunder yang diperoleh peneliti, social media Zetizen memiliki karakteristik konten berupa isi konten yang sangat ringkas, update, artsy, dan cenderung pamer. Konten sedapat mungkin bersifat native, challenging, current issue, dan menghibur, serta collaboration is a new friendship style.

Sebab social media sudah menjadi bagian dari keseharian generasi Z. Integrasi ketiga platform (halaman koran, website dan social media) mendorong peningkatan awareness terhadap produk Zetizen. Baik itu traffic website, readership koran, dan popularitas akun media sosial. Zetizen menggunakan LINE@, Instagram, Facebook, Twitter, sebagai social media yang banyak digunakan generasi $\mathrm{Z}$ atau masyarakat pada umumnya. Selain itu Zetizen juga membuat YouTube Channel. Dalam menjalankan platform tersebut, perlu diketahui apa saja yang dilakukan tim social media Zetizen. Seperti yang dijelaskan Social Media Coordinator Zetizen PT. Jawa Pos Group, Faisal Ramadhan, bahwa media sosial itu merupakan jembatan antara halaman koran menuju aplikasi yang digunakan para generasi Z. Konten-konten tersebut tidak dibuat begitu saja. Faisal Ramadhan mengatakan ada beberapa hal yang yang dibutuhkan tim social media Zetizen dalam membuat konten, dan memenuhi segala apa yang dibutuhkan. Zetizen juga memiliki waktu-waktu tertentu saat meng-upload konten social media Zetizen. Hal ini dilakukan agar konten yang di-upload banyak dilihat oleh generasi Z. Seperti yang dijelaskan Faisal Ramadhan, bahwa konten diupload saat pagi, siang, sore, dan malam hari. Kebutuhan konten video dalam social media juga sangat diperlukan. Seperti hasil wawancara bersama Faisal Ramadhan, bahwa dengan video itu akan lebih membuat daya tarik generasi $\mathrm{Z}$ untuk mengetahui aktivitas Zetizen itu seperti apa. 


\section{Offline Engagement}

Salah satu hal yang mampu mempertahankan loyalitas konsumen terhadap brand maupun produk adalah pelaksanaan offline engagement yang kontinyu dan terukur. Pendekatan kepada pembaca penting untuk terus dilakukan. Sebagai platform komunitas anak muda yang dirancang untuk menjadi yang terbesar di Indonesia, implementasi dari offline engagement Zetizen harus direncanakan matang untuk dapat diadaptasikan di berbagai kota. Impact yang diharapkan adalah active user yang terus bertambah, termasuk minat baca berita, informasi dan sebagainya.

Penerapan offline engagement di Zetizen pada dasarnya dikerjakan oleh seluruh divisi yang ada di departemen dan halaman anak muda Zetizen. Namun secara khusus ditangani divisi community Zetizen, yaitu operation dan community development.

Berdasarkan hasil wawancara peneliti kepada Supervisor Operasional Zetizen PT. Jawa Pos Group, Clarissa Diva Chanta Savirra, salah satu target dari offline engagement tersebut untuk menjalin komunitas terbesar di Indonesia, dan bagaimana mereka mendekatkan Zetizen dengan pembaca yang disasar, generasi Z.

Event yang digelar Zetizen cukup banyak. Clarissa Diva Chana Savirra menjelaskan bahwa Zetizen menggelar event lokal di berbagai provinsi, dan juga event nasional yang digelar demi mencapai visi misi Zetizen dan PT. Jawa Pos Group.

National Challenge merupakan event nasional Zetizen yang cukup banyak menambah member Zetizen. Melalui event ini, generasi $\mathrm{Z}$ juga banyak melakukan aksi positif sesuai kemampuannya masing-masing. Aksi positifnya juga diterbitkan di website dan halaman koran Zetizen. Hal ini juga membuat pembaca Zetizen lebih meningkat. Selain itu, Clarissa Diva Chana Savirra juga menjelaskan event lain yang digelar.

Offline activity Zetizen seperti event tersebut, menurut Clarissa Diva Chana Savirra bahwa dengan menerapkan cara itu bisa meningkatkan minat baca berita generasi Z.Bisa. Zetizen bukan hanya mengerjakan event, tapi kami mensinergikan tiga platform. Justru dengan adanya halaman koran, social media, website, dan event ini, dapat membantu meningkatkan minat baca koran, karena focus utamanya kami tetap koran. Di event ini bukan semata-mata event saja, tapi update tentang event itu bisa di akses di halaman koran, website, dan social media. Dengan itu anak-anak mau tidak mau kalau mau iktu event itu ya 
baca berita dan informasinya di halaman Zetizen. Akhirnya mereka bisa terbiasa dengan itu, mengakses informasinya di tiga platform yang kami terapkan. (Clarissa Diva Chana Savirra, Wawancara, Senin, 9 Oktober 2017).

Jawa Pos memang memiliki filosofi "part of the show", yaitu selalu ambil bagian dengan porsi besar, dominan dalam show, seperti event dan segala macam. Faisal Ash Shiddiq mengatakan, Zetizen termasuk departemen di Jawa Pos yang sangat banyak mengimplementasikan filosofi Jawa Pos lewat event. Sesuai hasil observasi yang dilakukan peneliti, keempat penerapan yang Zetizen PT. Jawa Pos lakukan itu memang diintegrasikan dan berjalan dengan baik. Tidak lepas pula kontrol, pengawasan serta evaluasi yang dilakukan para supervisor Zetizen. Mereka terlihat melaksanakan tugasnya secara maksimal, baik itu internal maupun eksternal Zetizen. Selama penelitian, peneliti melihat berbagai kesibukan para supervisor. Seperti memimpin rapat internal masing-masing divisi, mengikuti pertemuan dengan pimpinan, bertemu dengan partnership, membimbing rekan tim, mengikuti kegiatan kantor, dan lainnya.

\section{B. Tantangan Zetizen PT Jawa Pos Group Meningkatkan Minat Baca Generasi Z terhadap Berita}

Setiap profesi memiliki tantangan sendiri yang masing-masing berbeda antara satu profesi dengan profesi lainnya. Tantangan sebenarnya adalah dinamika kehidupan. Tidak pernah ada satu persoalan yang tidak menghadapi rintangan dan tantangan (Siagian, 2014: 180). Zetizen PT. Jawa Pos Group sebagai departemen dan halaman anak muda bagi generasi Z, memiliki salah satu visi untuk meningkatkan minat baca berita anak muda. Dengan berbagai aktivitas yang diimplementasikan crew Zetizen memungkinkan untuk mencapai visi tersebut, apalagi jika berjalan dengan baik berkat kerja sama tim dan kemampuan individu serta dukungan lainnya. Namun tentu ada tantangan tersendiri yang harus dihadapi Zetizen PT. Jawa Pos Group.

\section{Sumber Daya Manusia (SDM)}

a. Perbedaan Semangat serta Minimnya

SDM 
Setiap orang memiliki ke-mampuan dan semangat yang berbeda-beda. Apalagi sikap dan perilaku orang setiap daerah juga berbeda-beda. Seperti halnya Zetizen, halaman anak muda di bawah naungan PT. Jawa Pos Group ini tersebar di 34 provinsi yang ada di Indonesia. Memiliki pimpinan dan karyawan yang berbeda-beda. Begitupun dengan Sumber Daya Manusia (SDM) yang tersedia. Setiap media di daerah masing-masing di bawah naungan PT. Jawa Pos Group, memiliki berbagai macam aturan tertentu dalam menyediakan SDM. Ada yang banyak dan ada yang kurang Jawa Pos termasuk salah satu perusahaan media terbesar di Indonesia, tentunya membutuhkan reporter-reporter sebagai SDM yang andal di bidangnya. Khususnya di halaman anak muda Zetizen juga membutuhkan itu. Salah satu masalah adalah adanya reporter baru. Tentu perlu ada pengenalan dan pembelajaran terkait Zetizen. Karena Zetizen tidak seperti halaman atau rubrik lain. Zetizen memiliki banyak aktivitas selain menjadi seorang penulis berita.

b. Memiliki Keberanian, Memperbanyak Riset, dan Memahami Kondisi Anak Muda Seperti halnya divisi redaksional, divisi komunitas juga membutuhkan ide dalam menjalankan aktivitasnya. Selain itu divisi komunitas juga perlu ada keberanian untuk menentukan hal apa saja yang akan dilakukan. Riset juga sangat dibutuhkan, sehingga ada dasar untuk menggambarkan fenomena atau menemukan pengaruh dari sesuatu yang dibutuhkan. Masalah komuinkasi juga masih menjadi tantangan, apalagi Zetizen dikerjakan oleh ratusan orang yang tersebar se-Indonesia dengan latar belakang media dan kepribadian yang berbeda-beda.

Dibutuhkan pula keberanian untuk lebih dekat dan mengenal generasi Z. Sebab mengenal lebih dekat dengan seseorang adalah salah satu cara untuk mengetahui jauh lebih dalam tentang orang itu. Sehingga lebih mudah memahami masalah dan apa saja yang dibutuhkan. Begitupun dengan Zetizen, perlu lebih dekat dengan konsumennya, yakni generasi Z. Sehingga apa yang dibutuhkan generasi $\mathrm{Z}$ bisa disajikan berita yang sesuai dengan apa yang diinginkan, dengan harapan hasilnya generasi $\mathrm{Z}$ akan mau membacanya. Supervisor Operational Zetizen PT. Jawa Pos Group, Clarissa Diva Chanta Savirra mengatakan, jika ingin meningkatkan minat baca berita generasi $\mathrm{Z}$ lewat Zetizen, maka Zetizen harus lebih di atas generasi Z, serta lebih dekat lagi dengan mereka. 
Memahami kondisi anak muda juga sangat dibutuhkan Zetizen. Sebab Zetizen memiliki segmentasi pembaca generasi Z. Kondisi anak memang selalu berubah-ubah, sehingga Zetizen perlu lebih adaptif lagi seperti yang dijelaskan Faisal Ash Shiddiq sebelumnya.

Bila kondisi anak muda sudah dipahami, maka akan lebih mudah untuk membuat konten yang sesuai keinginan generasi Z.

\section{Konten}

a. Membuat Berita-Berita Zetizen Viral, Menarik, dan Komunikatif

Berita yang viral merupakan berita yang menyebar secara luas dan cepat, umumnya melalui media sosial dana internet. Disebut viral karena seperti virus yang cepat menyebar.

Setiap media tentu ingin berita atau informasi yang dibuat lebih viral daripada media lain. Sebab berita viral menjadi ukuran bahwa media itu mampu mendapatkan pembaca yang sangat banyak. Zetizen PT. Jawa Pos Group pun demikian. Seperti yang diungkapkan Editor Website Zetizen, Ratri Anugrah, bahwa berita Zetizen harus viral.

Untuk membuat berita menjadi viral, juga diperlukan ide-ide konten. Ide merupakan salah satu hal terpenting dalam menciptakan berita-berita yang bagus. Khususnya Zetizen, halaman anak muda ini memerlukan ide setiap orang dalam membuat tema berita yang akan diterbitkan. Idenya bagus, menarik, akan menghasilkan berita yang bagus pula, begitupun sebaliknya.

Videographer Zetizen, Gigha Penta Prakasa mengaku tertantang dalam hal menciptakan ide. "Tantangannya sih lebih ke penciptaan ide, jadi di sini kita harus memikirkan sesuatu ide yang nantinya dapat diterima oleh generasi Z." (Gigha Penta Prakasa, Wawancara, Kamis, 12 Oktober 2017).

Berita-berita Zetizen akan mudah menjadi viral dan menarik jika halaman koran juga berhasil di-layout dengan menarik. Besar kemungkinan pembaca akan suka dan nyaman untuk membaca berita. Jika halaman koran di-layout sembarangan maka orang akan sulit untuk membaca. Halaman koran yang menarik tentu berhubungan langsung dengan designer koran. 
b. Kurangnya Distribusi Media Berbicara mengenai pendistri- busian koran. Ada media yang memiliki distribusi koran yang banyak, ada juga yang sedikit, meskipun dalam satu group, tidak semua media memiliki penghasilan yang sama, sehingga distribusi tidak merata tentunya. Semakin tahun distribusi tentu akan ditambah, tergantung kebutuhan dan tentunya tergantung penghasilan masing-masing media. Sehingga dibutuhkan strategi untuk memaksimalkan halaman khususnya Zetizen dalam kondisi apapun, termasuk kekurangan distribusi.

c. Timeline Selalu Update dan Video Kreatif yang Menarik

Timeline sangat dibutuhkan dalam dunia media massa. Seperti Zetizen, timeline perlu dibuat dalam perencanaan ke depan. Misalnya tema dan konten apa saja yang akan diterbitkan. Inilah salah satu yang juga menjadi tantangan Zetizen. Setiap minggu harus membuat timeline yang tentu berbeda-beda dari sebelumnya.

Tantangan lain yaitu pembuatan video yang lebih menarik. Khususnya social media dan website Zetizen membutuhkan video-video yang menarik dan kreatif. Koordinator Social Media Zetizen PT. Jawa Pos Group, Faisal Ramadhan, dia merasa tertantang dalam hal pembuatan timeline dan video kreatif yang banyak dan menarik. Di era digital saat ini video kreatif tentu dibutuhkan untuk lebih dikenal lagi.

Sebab kembali ke ciri-ciri generasi Z, mereka cenderung aktif di dunia digital, termasuk menyukai video yang di-upload di social media, website, dan platform video lainnya. Tentulah untuk menarik minat baca mereka dibutuhkan video-video kreatif yang menarik. Namun inilah yang menjadi tantangan juga di Zetizen. Harus mencari tenaga yang bisa membuat video yang dibutuhkan. 


\section{Kesimpulan}

Implementasi yang dilakukan Zetizen PT. Jawa Pos Group dalam meningkatkan minat baca generasi $\mathrm{Z}$ terhadap berita yaitu mengintegrasikan halaman koran, website, social media, dan offline engagement. Semua harus saling terkait untuk mendapatkan hasil yang maksimal dalam mencapai visi misinya yang akan meningkatkan minat baca generasi Z.Tantangan yang dihadapi Zetizen PT. Jawa Pos Group dalam meningkatkan oleh generasi Z. Sebab kembali ke ciri-ciri generasi $Z$, mereka cenderung aktif di dunia digital, termasuk menyukai video yang di-upload di social media, website, dan platform video lainnya. Tentulah untuk menarik minat baca mereka dibutuhkan video-video kreatif yang menarik. Namun inilah yang menjadi tantangan juga di Zetizen. Harus mencari tenaga yang bisa membuat video yang dibutuhkan. minat baca generasi $Z$ terbagi dua yaitu; pertama Sumber Daya Manusia (SDM), yakni dari perbedaan semangat, minimnya SDM, dan memiliki keberanian, memperbanyak riset, dan memahami kondisi anak muda. Kedua adalah konten, yakni membuat berita-berita Zetizen menjadi viral, menarik, dan komunikatif, kurangnya distribusi media, dan timeline selalu update dan video kreatif yang menarik. 


\section{DAFTAR PUSTAKA}

Harian Jogja. "Dari 76 Negara, Minat Baca Siswa Indonesia Peringkat ke-69". Harian Jogja. 22 Maret 2016. http://m.harianjogja.com/baca/2016/03/22/penelitian-terbaru-dari-76negara-minat-baca-siswa-indonesia-peringkat-ke-69-703442 (18 Januari 2017).

Jawa Pos. 2017. "Corporate Jawa Pos". Situs Resmi Corporate Jawa Pos. http://www.corporate.jawapos.com. (8 Oktober 2017).

Republika. "Minat Membaca". Republika. 27 Februari 2015. http://www. republika.co.id/berita/koran/opini-koran/15/02/27/nkf7k917-minatmembaca (18 Januari 2017).

Siagian, Haidir Fitra. Peran dan Tanggung Jawab Jurnalis Muslim. Makassar: Alauddin University Press, 2014.

Zetizen. 2016. "Generasi Baby Boomer, X, Y, Z. Siapa Kasih Nama?". Situs Resmi Zetizen.http://www.zetizen.com/show/299/generasi-baby-boomer-x-y-zsiapa-yang-kasih-nama. (5 Desember 2016). 